\title{
Ameliorating effect of L-Ascorbate on protein and ascorbic acid content in different tissues of freshwater bivalve Lamellidens marginalis (Lamarck) on exposure to Lambda-cyhalothrin
}

\author{
Goswami, D.B. ${ }^{1}$ and Bhalla, R. ${ }^{2}$
}

Received: 02.04.2021

Revised: 12.05.2021

Accepted: 21.05.2021

\begin{abstract}
In the present investigation, Lamellidens marginalis the freshwater bivalves were treated with Lambda-cyhalothrin $(0.75$ ppm LC 50/10 value) alone and along with $L$-ascorbic acid $(50 \mathrm{mg} / \mathrm{L})$ chronically for 21 days. The values of protein and ascorbic acid were determined in the mantle, foot, gills, digestive glands, gonads, whole body of the Lamellidens marginalis on treating with Lambda-cyhalothrin alone and along with $\mathrm{L}$-Ascorbic acid $(50 \mathrm{mg} / \mathrm{L})$. The values of protein and ascorbic acid observed in all soft body tissues of Lamellidens marginalis were found to be decreased remarkably as compared to the values observed in animals kept in controlled environment. The amount of protein was observed maximum $(45.5268 \mathrm{mg} / \mathrm{L})$ in foot and minimum $(27.2648 \mathrm{mg} / \mathrm{L})$ in digestive glands of the freshwater bivalve. The amount of ascorbic acid was observed maximum $(0.8851 \mathrm{mg} / \mathrm{L})$ in digestive glands and minimum $(\mathrm{mg} / \mathrm{L})$ in foot of the freshwater bivalve. The depletion of amount of protein and ascorbic acid was observed less in animals exposed to Lambdacyhalothrin along with $50 \mathrm{mg} / \mathrm{l}$ ascorbic acid. In the present investigation it was observed that the percent protein and ascorbic acid concentrations recovered fast on $7^{\text {th }}, 14^{\text {th }}$ and $21^{\text {st }}$ days in the mantle, foot, gills, digestive glands, gonads, whole body tissues of Lamellidens marginalis on exposure to ascorbic acid than only treating the animals in the normal fresh water. This study determines that the L-Ascorbic acid has curative and protective properties against the severe damages may be caused by the Lambda-cyhalothrin.
\end{abstract}

Key words: Ascorbic acid, Lamellidens marginalis, Lambda-cyhalothrin, protein

\section{Introduction}

The freshwater bivalves found in natural environment play an important role in being a good source of food to the human population at large and the other aquatic organisms and also aquatic birds throughout the world in all water bodies (Malathi and Thippeswamy, 2013). For the development of the cities and countries there is a tremendous increase in the mechanised activities like siltation, construction of dams, chemical harvest and increasing level of pollution the number of freshwater bivalves is decreasing tremendously. Jaykumar et al. (2008) observed that exposure assessment of non-target animal populations like mussels, the excellent indicator organisms is essential to understand the potential effects of environmental contaminants. The pesticide Lambda-cyhalothrin is posing a potential threat to

\section{Author's Address}

${ }^{1}$ Swami Muktanand College of Science, Yeola, District Nashik (MS) India.

${ }^{2}$ Department of Zoology, LVH Arts, Sci. \& Comm. College, Nashik-(MS) India.

E-mail.: dr.resham.bhalla@gmail.com aquaculture in developing countries. Lambdacyhalothrin results in systemic intoxication when absorbed through the respiratory mucous membrane of aquatic organisms and proves to be highly toxic. This intoxicant interacts with certain membrane receptors, protein and ascorbic contents in the body of organisms and cause harmful effects by disturbing the physiological and biochemical processes and resulting into damage of different vital organs. Some animals, usually synthesize their own vitamin $\mathrm{C}$ and is highly concentrated in their liver part whereas other organisms have to take it as a supplement or through the external source through like Indian gooseberry, citrus fruits, green leafy vegetables as rich source of vitamin $\mathrm{C}$. The requirement of vitamin $\mathrm{C}$, as an antioxidant in the body is very less as it is required in micrograms but it is very essential for synthesis of collagen, maturation of RBC's maturation and detoxification of drugs with aromatic rings. Ascorbic acid is a potent reducing antioxidant agent, helps to fight bacterial infections, detoxification reactions, helps 
in building collagen in connective tissues, fibrous tissues, bones, teeth, skin and blood vessels, Fadime, (2017). Ascorbic acid also helps to detect modifications in different tissues induced due to exposure to chemicals and pollutants. Ascorbic acid, an antioxidant plays an important role in the cellular metabolic activities by interacting with other important biomolecules helps to determine the toxicant stress and other effects of pesticides and other pollutants. Ascorbic acid helps in maintaining the oxidation potential reactions and hence stability of the cells. Antioxidant properties of ascorbic acid helps in preventing the formation of free radicals from toxic water molecules enter inside the body, which may cause cellular damages and diseases. Therefore, the study of biochemical constituents like proteins and ascorbic acid would prove to be quite meaningful in understanding and estimating the nutritive value of the organisms and its further analysis would provide an explicit relationship between the basic biochemical components and the pesticide pollutants. Therefore, in the present study an attempt has been made to investigate the effect of pesticide stress on the biochemical constituents like protein and ascorbic acid and the recovery due to antioxidant properties of $\mathrm{L}$-ascorbic acid. Vitamin $\mathrm{C}$ is a potent reducing agent and scavenger of free radicals in biological systems (Durate, 2005). It is involved in the first line of antioxidant defence, protecting lipid membranes and proteins from oxidative damage. As a water soluble molecule vitamin $\mathrm{C}$ can work both inside and outside the cells and can neutralize free radicals and prevent free radical damage (Bindhumol et al., 2003).

\section{Materials and Methods}

The healthy and medium sized mussel Lamellidens marginalis were collected from the river Darna flowing through village Chehadi (Latitude $19^{\circ} 55^{\prime}$ 54.02"N, Longitude $73^{\circ} 55^{\prime} 30.42^{\prime \prime E) ~ N a s h i k ~ R o a d, ~}$ Maharashtra, packed in polythene along with sufficient amount of river water and were brought to the laboratory. The shells of fresh water bivalves were cleaned to remove the mud and were kept in trough with dechlorinated water and were fed with green algae and acclimatised for 3-4 days. For maintaining hygienic conditions for the bivalves, the water in the plastic trough was changed daily.
The freshwater bivalves were distributed in three sets equally with 10 animals of the same size and weight to find out the range of lethal concentrations of Lambda-cyhalothrin along with control set for evaluation of chronic toxicity for 7 days, 15 days and 21 days. Median lethal concentration, the regression equation between log concentration (X) in $\mathrm{ppm}$ and probit mortality (Y) was calculated using formula $\mathrm{Y}=\mathrm{a}+\log \mathrm{b}(\mathrm{X})$ and $95 \%$ fiducial limit was find out by probit analysis (Finney, 1971).

\section{Experimental Design: Set- I}

1. Animals designated Group A were maintained as Control.

2. Animals designated Group B were treated with 0.75 ppm Lambda-cyhalothrin for 21 days.

3. Animals designated Group $\mathrm{C}$ were treated with $0.75 \mathrm{ppm}$ Lambda-cyhalothrin along with $50 \mathrm{mg} / \mathrm{L} \mathrm{L}-A s c o r b i c$ acid for 21 days.

\section{Experimental design for recovery: Set- II}

1. Animals designated Group B were exposed to Lambda-cyhalothrin for 21 days from set divided into three groups for study of recovery by ascorbic acid.

2. Animals designated Group D were pre-exposed to Lambda-cyhalothrin were allowed to get cure normally in fresh water upto 21 days.

3. Animals designated Group E were pre- exposed to Lambda-cyhalothrin were allowed to get cure in $50 \mathrm{mg} / \mathrm{L}$ ascorbic acid upto 21 days.

For the whole period of experimental study, the freshwater bivalves were fed on fresh water algae collected from the river and washed properly. Animal were the troughs of set I and set II were taken out and dissected after every $7^{\text {th }}, 14^{\text {th }}$ and $21^{\text {st }}$ days interval and the tissues like mantle, foot, gills, digestive gland, gonads and whole soft body were dried at $80^{\circ} \mathrm{C}$ in an oven and the constant weights of all the tissues were obtained. The total protein levels were estimated by Lowry et al. (1951) in dried powders of all different tissues of control and experimental animals under study. The amount of ascorbic acid was determined by method of Roe (1967). The amount of total protein and ascorbic acid determined were calculated in terms of $\mathrm{mg}$ $/ 100 \mathrm{mg}$ of the dry weight tissue under study. Three replicates of each observation were taken for the confirmation of results of the tissues under experimental investigation. The difference in control and experimental animal group was tested 
for significance by using student' $t$ ' test and the percentage of decrease or increase over control was calculated for each value.

\section{Results and Discussion}

The experimental results observed for the total protein and ascorbic acid content in different tissues of fresh water bivalve Lamellidens marginalis after chronic exposure to Lambda-cyhalothrin without and with L-ascorbic acid and during recovery period are summarised in table 1 to 4 . The results observed revealed that, a marked decrease in the protein and ascorbic acid contents in the mantle, foot, gills, gonad, digestive glands and whole soft body tissues of the experimental freshwater bivalve, Lamellidens marginalis after chronic exposure to pesticides were observed and compared to freshwater bivalves maintained as control (Table 14). The progressive decrease in total protein and ascorbic acid contents were observed in mantle, foot, gills, digestive gland, gonads and whole soft body tissues of mantle, foot, gills, digestive gland, gonads and whole soft body with the increase in the exposure period. Proteins are among the most abundant biological macromolecules and show extreme versatility in their functions. Proteins are vital biomolecules in performing cellular functions. All enzymes are protein in nature and act as biocatalysts in controlling sub-cellular functions of the body. Many enzymes, coenzymes, intermediate proteins and amino acids involved in the metabolism of proteins are studied in many animals.In the present investigation, the decrease in total protein content might be due to highly metabolic potency and efficiency of the digestive gland as compared to other tissues like gill and whole-body. The digestive gland seems to be the main site of degradation and detoxification of pesticides. Waykar and Tambe (2014) reported that freshwater bivalve Parreysia cylindrica exposed to pesticide decreased the protein content in soft body tissues. Mahajan et al. (2015) studied cure action of ascorbic acid in arsenic induced alteration in protein contents of Lamellidens marginalis. Rahane and Bhalla (2019) reported that bivalve species inhabiting at higher level of polluted site showed low level of protein content, while bivalve species inhabiting at low level of polluted site showed higher level of protein content. The low level of ascorbic acid content was observed in different soft body tissues of bivalve Lamellidens marginalis (L) under investigation on chronic exposure for 21 days to Lambda-cyhalothrin might be due to bivalves' species exposed to higher level of pesticide exert stress on freshwater bivalves. The low levels of ascorbic acid resulted the toxic stress caused by Lambdacyhalothrin may be due to the involvement of ascorbic acid in detoxification and repairing of injuries caused in tissues and to cope up against the stress. The decrease in ascorbic acid content indicated that it may be involved in counteracting damage caused by oxidative stress. Kamble (2011) studied organochlorine and organophosphorus impact on ascorbic acid content in Lamellidens corrianus and reported that there was significant decrease in ascorbic acid content. Ahmad et. al. (2012) showed that in organs like foot and gill showed elevation in ascorbic acid due to inability of these organs to form thiol compounds being non enzymatic antioxidant's role. Tambe and Pulate (2015) studied ascorbic acid recovery action against dichlorovos induced changes in protein contents of Parreysia cylindrica. The amount of protein and ascorbic acid depletion was much reduced on combined exposure to Lambdacyhalothrin with $50 \mathrm{mg} / \mathrm{L}$ of L-ascorbic acid. Antioxidants are potent to reduce the damage caused by oxidation resulted due to formation of free radicals. The formation of free radicals is beyond the protective capability of the antioxidants defences resulting into the occurrence of oxidative stress. In the process, the antioxidants themselves may become oxidized, and may block the process of oxidation by neutralizing free radical. The fast recovery in the protein and ascorbic acid content in different tissues of freshwater bivalves pre-exposed to Lambda-cyhalothrin occurred in the presence of L- ascorbic acid than those allowed to cure naturally in normal freshwater. This present study investigates that the use of L-ascorbic acid helps in protecting the tissues from oxidative damage caused on exposure to pesticides. Mahajan and Zhambare (2006) studied the protection by ascorbic acid against the arsenic induced alterations in ascorbic acid levels in freshwater bivalve, Lamellidens marginalis. Rahane and Bhalla (2018) observed the similar results of toxicant stress on protein and ascorbic acid contents in different tissues of freshwater bivalve Parreysia cylindrica. Bhalla (2019) reported the methomyl and Lambdacyhalothrin induced alterations in the protein content and recovery due to L-ascorbic acid in different tissues of the freshwater bivalve, Lamellidens marginalis (lamarck). 
Goswami and Bhalla

Table 1: Total protein content in different soft body tissues of Lamellidens marginalis after chronic exposure to Lambda-Cyhalothrin (0.75 ppm) without and with ascorbic acid

\begin{tabular}{|c|c|c|c|c|c|c|c|c|c|c|}
\hline \multirow[t]{2}{*}{ SN } & \multirow[t]{2}{*}{ Tissue } & \multicolumn{3}{|l|}{$\begin{array}{l}\text { Control } \\
\text { (A) }\end{array}$} & \multicolumn{3}{|c|}{ Lambda-Cyhalothrin (0.75 ppm). (B) } & \multicolumn{3}{|c|}{$\begin{array}{l}\text { Lambda-Cyhalothrin (0.75 ppm). (B) } \\
\text { + Ascorbic Acid. (50 mg/l) (C) }\end{array}$} \\
\hline & & 7 days & 14 days & 21 days & 7 days & 14 days & 21 days & 7 days & 14 days & 21 days \\
\hline 1 & Mantle & $\begin{array}{l}49.8168 \\
\pm 1.48\end{array}$ & $\begin{array}{l}48.7195 \\
\pm 1.68\end{array}$ & $\begin{array}{l}48.1244 \\
\pm 1.37\end{array}$ & $\begin{array}{l}33.4289 * * \\
\pm 1.25 \\
(-32.90)\end{array}$ & $\begin{array}{l}27.7692 * * * \\
\pm 1.56 \\
(-43.00)\end{array}$ & $\begin{array}{l}23.7358 * * \\
\pm 1.77 \\
(-48.39)\end{array}$ & $\begin{array}{l}32.4212^{*} \\
\pm 1.42 \\
(-22.87)\end{array}$ & $\begin{array}{l}34.9560^{* * *} \\
\pm 1.54 \\
(-28.25)\end{array}$ & $\begin{array}{l}28.3648 * * \\
\pm 1.48 \\
(-41.06)\end{array}$ \\
\hline 2 & Foot & $\begin{array}{l}64.4688 \\
\pm 1.55\end{array}$ & $\begin{array}{l}64.2589 \\
\pm 1.84\end{array}$ & $\begin{array}{l}63.8341 \\
\pm 1.72\end{array}$ & $\begin{array}{l}47.8864 * \\
\pm 1.58 \\
(-25.72)\end{array}$ & $\begin{array}{l}43.9560 * * \\
\pm 1.39 \\
(-31.59)\end{array}$ & $\begin{array}{l}37.1892 * * \\
\pm 1.78 \\
(-40.34)\end{array}$ & $\begin{array}{l}55.6080^{* * *} \\
\pm 1.98 \\
(-13.74)\end{array}$ & $\begin{array}{l}49.7472 * * \\
\pm 1.43 \\
(-22.56)\end{array}$ & $\begin{array}{l}45.5268 * * \\
\pm 1.37 \\
(-28.68)\end{array}$ \\
\hline 3 & Gills & $\begin{array}{l}57.1428 \\
\pm 1.29\end{array}$ & $\begin{array}{l}56.6335 \\
\pm 1.18\end{array}$ & $\begin{array}{l}56.2148 \\
\pm 1.63\end{array}$ & $\begin{array}{l}32.1692 * * * \\
\pm 0.89 \\
(-43.70)\end{array}$ & $\begin{array}{l}28.3736^{*} \\
\pm 1.33 \\
(-49.90)\end{array}$ & $\begin{array}{l}25.3525 * * * \\
\pm 2.01 \\
(-56.73)\end{array}$ & $\begin{array}{l}39.8560 * * \\
\pm 1.29 \\
(-30.25)\end{array}$ & $\begin{array}{l}34.0952 * * * \\
\pm 1.36 \\
(-39.80)\end{array}$ & $\begin{array}{l}31.8604^{*} \\
\pm 1.86 \\
(-43.32)\end{array}$ \\
\hline 4 & $\begin{array}{l}\text { Digestive } \\
\text { glands }\end{array}$ & $\begin{array}{l}52.7472 \\
\pm 1.59\end{array}$ & $\begin{array}{l}51.9780 \\
\pm 1.81\end{array}$ & $\begin{array}{l}50.6845 \\
\pm 1.42\end{array}$ & $\begin{array}{l}27.2344 * * \\
\pm 1.59 \\
(-48.37)\end{array}$ & $\begin{array}{l}18.9675 * * * \\
\pm 1.49 \\
(-63.51)\end{array}$ & $\begin{array}{l}16.6824 * * \\
\pm 1.35 \\
(-65.31)\end{array}$ & $\begin{array}{l}44.9158^{*} \\
\pm 2.12 \\
(-14.85)\end{array}$ & $\begin{array}{l}39.2908 * * \\
\pm 1.88 \\
(-24.41)\end{array}$ & $\begin{array}{l}27.2648 * * * \\
\pm 1.62 \\
(-46.21)\end{array}$ \\
\hline 5 & Gonad & $\begin{array}{l}51.9103 \\
\pm 0.98\end{array}$ & $\begin{array}{l}50.2492 \\
\pm 0.74\end{array}$ & $\begin{array}{l}50.1165 \\
\pm 1.50\end{array}$ & $\begin{array}{l}36.1268^{*} \\
\pm 1.12 \\
(-30.41)\end{array}$ & $\begin{array}{l}31.5246^{* *} \\
\pm 1.90 \\
(-37.26)\end{array}$ & $\begin{array}{l}26.4593^{*} \\
\pm 1.35 \\
(-45.28)\end{array}$ & $\begin{array}{l}38.8452 * * \\
\pm 1.30 \\
(-25.17)\end{array}$ & $\begin{array}{l}32.6812 * \\
\pm 0.87 \\
(-34.96)\end{array}$ & $\begin{array}{l}30.6124 * * \\
\pm 1.78 \\
(-38.92)\end{array}$ \\
\hline 6 & $\begin{array}{l}\text { Whole } \\
\text { soft body }\end{array}$ & $\begin{array}{l}61.5384 \\
\pm 2.06\end{array}$ & $\begin{array}{l}61.1644 \\
\pm 1.97\end{array}$ & $\begin{array}{l}60.2482 \\
\pm 1.78\end{array}$ & $\begin{array}{l}44.3516^{* *} \\
\pm 1.73 \\
(-27.93)\end{array}$ & $\begin{array}{l}34.9560^{*} \\
\pm 2.09 \\
(-42.85)\end{array}$ & $\begin{array}{l}29.5492 * * * \\
\pm 1.44 \\
(-49.16)\end{array}$ & $\begin{array}{l}48.4772 * * * \\
\pm 1.93 \\
(-21.22)\end{array}$ & $\begin{array}{l}37.8864 * \\
\pm 1.73 \\
(-38.06)\end{array}$ & $\begin{array}{l}35.5616^{* *} \\
\pm 1.91 \\
(-40.97)\end{array}$ \\
\hline
\end{tabular}

1. Values expressed as $\mathrm{mg} / 100 \mathrm{mg}$ dry wt. of tissue 2. (+) or (-) indicate percent variation over control 3. \pm indicate S.D. of three observation 4. Values are significant at $* P<0.001, * * P<0.01, * * * P<0.055$. NS (Not significant) 
Table 2: Total protein content in different soft body tissues of Lamellidens marginalis after chronic exposure to Lambda-Cyhalothrin $(0.75 \mathrm{ppm})$ and its subsequent recovery in normal water and in ascorbic acid $50 \mathrm{mg} / \mathrm{l}$

\begin{tabular}{|c|c|c|c|c|c|c|c|c|}
\hline \multirow[t]{2}{*}{$\mathbf{S ~ N}$} & \multirow[t]{2}{*}{ Tissue } & \multirow{2}{*}{$\begin{array}{l}\text { Lambda- } \\
\text { cyhalothrin } \\
(0.75 \mathrm{ppm})(\mathrm{B}) \\
21 \text { days }\end{array}$} & \multicolumn{3}{|c|}{$\begin{array}{l}\text { Recovery in normal water } \\
\text { (i) }\end{array}$} & \multicolumn{3}{|c|}{$\begin{array}{l}\text { Recovery in Ascorbic Acid (50 mg/l) } \\
\text { (ii) }\end{array}$} \\
\hline & & & 7 days & 14 days & 21 days & 7 days & 14 days & 21 days \\
\hline 1 & Mantle & $\begin{array}{l}23.7358 * * \\
\pm 1.77 \\
(-48.39)\end{array}$ & $\begin{array}{l}28.9747 * * \\
\pm 1.45 \\
(+16.21)\end{array}$ & $\begin{array}{l}30.7952 * * \\
\pm 1.65 \\
(+21.16)\end{array}$ & $\begin{array}{l}32.6212 * * \\
\pm 1.21 \\
(+31.33)\end{array}$ & $\begin{array}{l}34.6645^{* * *} \\
\pm 1.50 \\
(+27.48)\end{array}$ & $\begin{array}{l}36.9612 * * \\
\pm 2.04 \\
(+36.73)\end{array}$ & $\begin{array}{l}41.0656^{* * *} \\
\pm 1.30 \\
(+65.33)\end{array}$ \\
\hline 2 & Foot & $\begin{array}{l}37.1892 * * \\
\pm 1.78 \\
(-40.34)\end{array}$ & $\begin{array}{l}41.2763^{*} \\
\pm 1.80 \\
(+8.14)\end{array}$ & $\begin{array}{l}43.7812^{* * *} \\
\pm 1.44 \\
(+12.86)\end{array}$ & $\begin{array}{l}46.0948 * * \\
\pm 1.90 \\
(+21.03)\end{array}$ & $\begin{array}{l}45.2556^{* *} \\
\pm 1.88 \\
(+13.50)\end{array}$ & $\begin{array}{l}49.9237 * * * \\
\pm 1.24 \\
(+23.47)\end{array}$ & $\begin{array}{l}57.8384 * * \\
\pm 1.49 \\
(+52.13)\end{array}$ \\
\hline 3 & Gills & $\begin{array}{l}25.3525 * * * \\
\pm 2.01 \\
(-56.73)\end{array}$ & $\begin{array}{l}26.7488^{*} \\
\pm 1.17 \\
(+9.48)\end{array}$ & $\begin{array}{l}30.3689^{*} \\
\pm 1.40 \\
(+20.58)\end{array}$ & $\begin{array}{l}33.4604^{*} \\
\pm 2.53 \\
(+37.57)\end{array}$ & $\begin{array}{l}33.3504^{*} \\
\pm 1.37 \\
(+24.78)\end{array}$ & $\begin{array}{l}38.6513 * * \\
\pm 1.73 \\
(+38.35)\end{array}$ & $\begin{array}{l}45.7472 * * \\
\pm 2.13 \\
(+80.27)\end{array}$ \\
\hline 4 & $\begin{array}{l}\text { Digesti } \\
\text { ve } \\
\text { glands }\end{array}$ & $\begin{array}{l}16.6824 * * \\
\pm 1.35 \\
(-65.31)\end{array}$ & $\begin{array}{l}20.2662 * * \\
\pm 1.25 \\
(+15.13)\end{array}$ & $\begin{array}{l}22.9822 * * \\
\pm 1.70 \\
(+24.80)\end{array}$ & $\begin{array}{l}26.1300 * * \\
\pm 1.77 \\
(+48.61)\end{array}$ & $\begin{array}{l}26.7692 * * * \\
\pm 1.53 \\
(+35.19)\end{array}$ & $\begin{array}{l}29.1326^{*} \\
\pm 1.26 \\
(+54.32)\end{array}$ & $\begin{array}{l}35.6557 * * * \\
\pm 1.69 \\
(+82.89)\end{array}$ \\
\hline 5 & Gonad & $\begin{array}{l}26.4593^{*} \\
\pm 1.35 \\
(-45.28)\end{array}$ & $\begin{array}{l}28.1226^{* *} \\
\pm 0.85 \\
(+13.13)\end{array}$ & $\begin{array}{l}33.9713^{*} \\
\pm 1.45 \\
(+19.98)\end{array}$ & $\begin{array}{l}35.4435 * * \\
\pm 1.66 \\
(+29.25)\end{array}$ & $\begin{array}{l}36.3715^{*} \\
\pm 0.79 \\
(+25.34)\end{array}$ & $\begin{array}{l}39.9715^{* * *} \\
\pm 1.06 \\
(+33.36)\end{array}$ & $\begin{array}{l}45.8508 * * \\
\pm 0.95 \\
(+63.19)\end{array}$ \\
\hline 6 & $\begin{array}{l}\text { Whole } \\
\text { soft } \\
\text { body }\end{array}$ & $\begin{array}{l}29.5492 * * * \\
\pm 1.44 \\
(-49.16)\end{array}$ & $\begin{array}{l}34.5952 * \\
\pm 1.35 \\
(+11.64)\end{array}$ & $\begin{array}{l}42.8760 * * * \\
\pm 1.83 \\
(+35.70)\end{array}$ & $\begin{array}{l}44.5164 * * \\
\pm 1.65 \\
(+45.34)\end{array}$ & $\begin{array}{l}44.9780 * * \\
\pm 1.36 \\
(+30.45)\end{array}$ & $\begin{array}{l}48.2944 * * * \\
\pm 1.95 \\
(+44.59)\end{array}$ & $\begin{array}{l}55.5640 \text { *** } \\
\pm 1.87 \\
(+74.37)\end{array}$ \\
\hline
\end{tabular}

1. Values expressed as $\mathbf{m g} / \mathbf{1 0 0 m g}$ dry wt. of tissue 2. $(+)$ or $(-)$ indicate percent variation over control 3. \pm indicate $S . D$. of three observation 4 . Values are significant at $* P<0.001, * * P<0.01, * * * P<0.055$. NS (Not significant) 
Table 3: Total ascorbic acid content in different soft body tissues of Lamellidens marginalis after chronic exposure to LambdaCyhalothrin (0.75 ppm) without and with ascorbic acid

\begin{tabular}{|c|c|c|c|c|c|c|c|c|c|c|}
\hline \multirow[t]{2}{*}{ SN } & \multirow[t]{2}{*}{ Tissue } & \multicolumn{3}{|l|}{$\begin{array}{l}\text { Control } \\
\text { (A) }\end{array}$} & \multicolumn{3}{|c|}{$\begin{array}{l}\text { Lambda-Cyhalothrin (0.75 ppm) } \\
\text { (B) }\end{array}$} & \multicolumn{3}{|c|}{$\begin{array}{l}\text { Lambda-Cyhalothrin (0.75 ppm) + } \\
\text { Ascorbic Acid (50 mg/l) (C) }\end{array}$} \\
\hline & & 7 days & 14 days & 21 days & 7 days & 14 days & 21 days & 7 days & 14 days & 21 days \\
\hline 1 & Mantle & $0.9245 \pm 1.84$ & $\begin{array}{l}0.9228 \\
\pm 1.28\end{array}$ & $\begin{array}{l}0.9280 \\
\pm 1.52\end{array}$ & $\begin{array}{l}0.6675^{* *} \\
\pm 0.89 \\
(-27.80)\end{array}$ & $\begin{array}{l}0.6327 * \\
\pm 1.15 \\
(-31.44)\end{array}$ & $\begin{array}{l}0.5942 * * \\
\pm 1.27 \\
(-45.08)\end{array}$ & $\begin{array}{l}0.7189 * * \\
\pm 1.47 \\
(-21.16)\end{array}$ & $\begin{array}{l}0.6835^{*} \\
\pm 0.94 \\
(-27.01)\end{array}$ & $\begin{array}{l}0.6716^{* *} \\
\pm 1.55 \\
(-35.56)\end{array}$ \\
\hline 2 & Foot & $0.4654 \pm 1.39$ & $\begin{array}{l}0.4598 \\
\pm 1.71\end{array}$ & $\begin{array}{l}0.4514 \\
\pm 1.37\end{array}$ & $\begin{array}{l}0.3508^{* *} \\
\pm 1.75 \\
(-24.62)\end{array}$ & $\begin{array}{l}0.3176^{* *} \\
\pm 1.73 \\
(-30.93)\end{array}$ & $\begin{array}{l}0.3654 * * * \\
\pm 1.63 \\
(-40.68)\end{array}$ & $\begin{array}{l}0.3978 * * \\
\pm 1.56 \\
(-16.67)\end{array}$ & $\begin{array}{l}0.3604 * * * \\
\pm 1.29 \\
(-23.79)\end{array}$ & $\begin{array}{l}0.4617 * * * \\
\pm 1.56 \\
(-32.56)\end{array}$ \\
\hline 3 & Gills & $1.1686 \pm 1.65$ & $\begin{array}{l}1.1536 \\
\pm 1.82\end{array}$ & $\begin{array}{l}1.1435 \\
\pm 1.25\end{array}$ & $\begin{array}{l}0.8477^{*} \\
\pm 1.16 \\
(-27.46)\end{array}$ & $\begin{array}{l}0.7124^{* *} \\
\pm 1.51 \\
(-38.24)\end{array}$ & $\begin{array}{l}0.5795 * * * \\
\pm 1.31 \\
(-50.81)\end{array}$ & $\begin{array}{l}0.8894 * * * \\
\pm 1.21 \\
(-23.46)\end{array}$ & $\begin{array}{l}0.7487^{*} \\
\pm 1.83 \\
(-27.38)\end{array}$ & $\begin{array}{l}0.7626^{* *} \\
\pm 1.66 \\
(-37.94)\end{array}$ \\
\hline 4 & $\begin{array}{l}\text { Digestive } \\
\text { glands }\end{array}$ & $1.4817 \pm 1.59$ & $\begin{array}{l}1.4284 \\
\pm 1.93\end{array}$ & $\begin{array}{l}1.4284 \\
\pm 1.55\end{array}$ & $\begin{array}{l}0.9841 * * \\
\pm 1.44 \\
(-33.58)\end{array}$ & $\begin{array}{l}0.7816^{* * *} \\
\pm 1.84 \\
(-45.28)\end{array}$ & $\begin{array}{l}0.5963 * * * \\
\pm 1.42 \\
(-59.12)\end{array}$ & $\begin{array}{l}1.0995^{* *} \\
\pm 1.75 \\
(-26.27)\end{array}$ & $\begin{array}{l}0.9282 * * * \\
\pm 1.78 \\
(-36.14)\end{array}$ & $\begin{array}{l}0.8851 * \\
\pm 1.04 \\
(-44.55)\end{array}$ \\
\hline 5 & Gonad & $1.3256 \pm 1.27$ & $\begin{array}{l}1.3245 \\
\pm 1.61\end{array}$ & $\begin{array}{l}1.3189 \\
\pm 1.76\end{array}$ & $\begin{array}{l}0.9477^{*} \\
\pm 1.79 \\
(-28.51)\end{array}$ & $\begin{array}{l}0.7864 * * \\
\pm 1.92 \\
(-40.63)\end{array}$ & $\begin{array}{l}0.7942 * * \\
\pm 1.13 \\
(-42.38)\end{array}$ & $\begin{array}{l}0.9643 * * * \\
\pm 1.25 \\
(-25.75)\end{array}$ & $\begin{array}{l}0.8715^{* *} \\
\pm 1.63 \\
(-32.69)\end{array}$ & $\begin{array}{l}0.8451^{* * *} \\
\pm 1.17 \\
(-34.26)\end{array}$ \\
\hline 6 & $\begin{array}{l}\text { Whole } \\
\text { soft body }\end{array}$ & $0.9688 \pm 1.07$ & $\begin{array}{l}0.9450 \\
\pm 1.18\end{array}$ & $\begin{array}{l}0.9397 \\
\pm 1.46\end{array}$ & $\begin{array}{l}0.7324 * * * \\
\pm 1.08 \\
(-24.40)\end{array}$ & $\begin{array}{l}0.6125^{*} \\
\pm 1.77 \\
(-35.18)\end{array}$ & $\begin{array}{l}0.5635 * * * \\
\pm 1.31 \\
(-48.16)\end{array}$ & $\begin{array}{l}0.7963^{*} \\
\pm 1.98 \\
(-19.87)\end{array}$ & $\begin{array}{l}0.6758 * * \\
\pm 1.74 \\
(-31.66)\end{array}$ & $\begin{array}{l}0.5968^{* *} \\
\pm 1.65 \\
(-38.56)\end{array}$ \\
\hline
\end{tabular}

1. Values expressed as $\mathrm{mg} / 100 \mathrm{mg}$ dry wt. of tissue

2. $(+)$ or $(-)$ indicate percent variation over control

3. \pm indicate S.D. of three observation

4. Values are significant at $* P<0.001, * * P<0.01, * * * P<0.05$ 5. NS (Not significant) 
Table 4: Total ascorbic acid content in different soft body tissues of Lamellidens marginalis after chronic exposure to LambdaCyhalothrin (0.75 ppm) and its subsequent recovery in normal water and in Ascorbic acid $50 \mathrm{mg} / \mathrm{l}$.

\begin{tabular}{|c|c|c|c|c|c|c|c|c|}
\hline \multirow[t]{2}{*}{$\begin{array}{l}\text { Sr. } \\
\text { No. }\end{array}$} & \multirow[t]{2}{*}{ Tissue } & \multirow{2}{*}{$\begin{array}{l}\text { lambda-cyhalothrin } \\
(0.75 \text { ppm) (B) } \\
21 \text { days }\end{array}$} & \multicolumn{3}{|c|}{$\begin{array}{l}\text { Recovery in normal water } \\
\text { (i) }\end{array}$} & \multicolumn{3}{|c|}{ Recovery in Ascorbic Acid (50 mg/l) (ii) } \\
\hline & & & 7 days & 14 days & 21 days & 7 days & 14 days & 21 days \\
\hline 1 & Mantle & $\begin{array}{l}0.5942 * * \\
\pm 1.27(-45.08)\end{array}$ & $\begin{array}{l}0.6617 * * \\
\pm 1.23(+9.69)\end{array}$ & $\begin{array}{l}0.6486^{* *} \\
\pm 0.68 \\
(+14.43)\end{array}$ & $\begin{array}{l}0.7122^{*} \\
\pm 0.67 \\
(+25.65)\end{array}$ & $\begin{array}{l}0.6978^{*} \\
\pm 1.04 \\
(+23.11)\end{array}$ & $\begin{array}{l}0.8023 * * * \\
\pm 1.15 \\
(+41.55)\end{array}$ & $\begin{array}{l}0.9645^{* *} \\
\pm 1.22 \\
(+70.17)\end{array}$ \\
\hline 2 & Foot & $\begin{array}{l}0.3654 * * * \\
\pm 1.63 \\
(-40.68)\end{array}$ & $\begin{array}{l}0.3196 * * * \\
\pm 1.92 \\
(+12.34)\end{array}$ & $\begin{array}{l}0.3349 * \\
\pm 1.13 \\
(+17.89)\end{array}$ & $\begin{array}{l}0.3825 * * \\
\pm 1.44 \\
(+35.16)\end{array}$ & $\begin{array}{l}0.3975^{* *} \\
\pm 1.66 \\
(+33.35)\end{array}$ & $\begin{array}{l}0.4397 * * \\
\pm 1.26 \\
(+52.29)\end{array}$ & $\begin{array}{l}0.4905 * * * \\
\pm 1.51 \\
(+74.35)\end{array}$ \\
\hline 3 & Gills & $\begin{array}{l}0.5795 * * * \\
\pm 1.31 \\
(-50.81)\end{array}$ & $\begin{array}{l}0.7642 * * \\
\pm 1.74 \\
(+18.12)\end{array}$ & $\begin{array}{l}0.8256 * * * \\
\pm 1.78 \\
(+24.60)\end{array}$ & $\begin{array}{l}0.8995 * * \\
\pm 1.59 \\
(+40.25)\end{array}$ & $\begin{array}{l}0.8991 * * * \\
\pm 1.73 \\
(+39.25)\end{array}$ & $\begin{array}{l}0.9917 * \\
\pm 0.85 \\
(+50.62)\end{array}$ & $\begin{array}{l}1.2653^{*} \\
\pm 0.91 \\
(+96.60)\end{array}$ \\
\hline 4 & $\begin{array}{l}\text { Digestive } \\
\text { glands }\end{array}$ & $\begin{array}{l}0.5963^{* * *} \\
\pm 1.42 \\
(-59.12)\end{array}$ & $\begin{array}{l}0.7193^{*} \\
\pm 1.25 \\
(+10.59)\end{array}$ & $\begin{array}{l}0.7529 * * * \\
\pm 1.07 \\
(+19.47)\end{array}$ & $\begin{array}{l}0.8283^{* *} \\
\pm 0.98 \\
(+28.45)\end{array}$ & $\begin{array}{l}0.8085^{*} \\
\pm 1.33 \\
(+26.87)\end{array}$ & $\begin{array}{l}0.9776^{* *} \\
\pm 1.39 \\
(+49.25)\end{array}$ & $\begin{array}{l}1.1942^{* *} \\
\pm 1.87 \\
(+85.71)\end{array}$ \\
\hline 5 & Gonad & $\begin{array}{l}0.7942^{* *} \\
\pm 1.13 \\
(-42.38)\end{array}$ & $\begin{array}{l}0.8869 * * \\
\pm 1.51 \\
(+6.47)\end{array}$ & $\begin{array}{l}1.0998^{* *} \\
\pm 1.39 \\
(+12.05)\end{array}$ & $\begin{array}{l}1.1584^{*} \\
\pm 1.41 \\
(+20.77)\end{array}$ & $\begin{array}{l}1.0984 * * * \\
\pm 1.55 \\
(+19.55)\end{array}$ & $\begin{array}{l}1.3774^{*} \\
\pm 1.49 \\
(+41.74)\end{array}$ & $\begin{array}{l}1.4998 * * * \\
\pm 1.78 \\
(+65.09)\end{array}$ \\
\hline 6 & $\begin{array}{l}\text { Whole } \\
\text { soft body }\end{array}$ & $\begin{array}{l}0.5635 * * * \\
\pm 1.31 \\
(-48.16)\end{array}$ & $\begin{array}{l}0.6232 * * \\
\pm 2.04 \\
(+11.37)\end{array}$ & $\begin{array}{l}0.6928 * * \\
\pm 2.07 \\
(+24.22)\end{array}$ & $\begin{array}{l}0.7775 * * \\
\pm 1.76 \\
(+41.71)\end{array}$ & $\begin{array}{l}0.7864 * * \\
\pm 1.77 \\
(+39.66)\end{array}$ & $\begin{array}{l}0.8274 * * \\
\pm 1.65 \\
(+49.08)\end{array}$ & $\begin{array}{l}0.9985 * * \\
\pm 1.83 \\
(+78.82)\end{array}$ \\
\hline
\end{tabular}

1. Values expressed as $\mathrm{mg} / 100 \mathrm{mg}$ dry wt. of tissue

2. $(+)$ or $(-)$ indicate percent variation over control

3. \pm indicate S.D. of three observation

4. Values are significant at $* P<0.001, * * P<0.01, * * * P<0.05$ 5. NS (Not significant) 


\section{Goswami and Bhalla}

It may be concluded that the rate of recovery from pesticide induced damage gets faster on exposure to L-ascorbic acid indicating the trend leading towards the normalization of physiological disturbances caused on exposure to pesticides.

\section{Conclusion}

In the present study obtained results showed the low level of proteins and ascorbic acid, in different soft body tissues of freshwater bivalve Lamellidens marginalis (Lamarck) when exposed to Lambdacyhalothrin and the amount was found more in foot than was found in digestive gland. Further on treatment with L-Ascorbic acid recovery in protein

\section{References}

Ahmad, I., Mohmood, I., Ceolho, J. P., Pacheco, M., Santos, M. A., Duarte, A. C. Pereira, E. 2012. Role of nonenzymatic antioxidants on the bivalves' adaptation to environmental mercury: Organ-specificities and age effect in Scrobicularia plana inhabiting a contaminated lagoon. Environmental pollution, 1(13): 218-225.

Bhalla, R. 2019. Methomyl and Lambda-cyhalothrin induced alterations in the protein content and recovery due to Lascorbic acid in different tissues of the freshwater bivalve, Lamellidens marginalis (Lamarck). International Journal of Global Science Research, 6 (1): 653-662.

Bindhumol, V., Chitra, K. C., Mathur, P. P. 2003. A induces reactive oxygen species generation in the liver of male rats. Toxicology, 188: 117-124.

Duarte, T. L. and Lunec, J. 2005. When is an antioxidant not an antioxidant? A review of novel actions and reactions of vitamin C. Free Radical Research, 39(7): 671-686.

Fadime Eryılmaz Pehlivan, 2017. Vitamin C: An Antioxidant Agent http://dx.doi.org/10.5772/intechopen.69660

Finney, D. J. 1971. Probit Analysis (3rd edition). Cambridge University Press, Cambridge, UK.

Jayakumar, P., Jothivel, N. and Paul, V. 2008. Heavy metals induced alterations in the acid phosphates activity in the edible freshwater mussel Lamellidens marginalis (Lamarck). The International Journal Toxicology, 5(2): DOI: $10.5580 / 2559$.

Kamble, V. S., Gavhane, U. V. and Rao, K. R. 2011. Impact of Organochlorine and Organophosphorus pesticides on ascorbic acid content in fresh water lamellibranch mollusc Lamellidens corrianus during monsoon season. Indian Journal of Fundamental and Applied Life Sciences, 1(2): 146-149. and ascorbic acid content occurred clearly indicating the preventive and curative antioxidant properties of L- ascorbic acid. Consequently, ascorbic acid can act as a strong, efficient and cheap antioxidant agent, whereas at the same time it can behave as a radical promoter and produce dangerous species in living systems.

\section{Acknowledgement}

The authors are grateful to University Grants Commission for the financial assistance and to the coordinator, MGV and the principal, LVH ASCC, Panchavati, Nasik for encouragement and providing library and laboratory facilities.

Lowry, O. M, Rosenbroughty, N. J., Farr A. L., Randall, R. F. 1951. Protein estimation with folin phenol reagent. Journal of Biochemistry, 193: 265-275.

Mahajan, S. S., Zhambare, S. P., Phanse, M. P. 2015. Cure of arsenic induced alterations in the protein levels of an experimental model, Lamellidens marginalis by LAscorbic acid. BionanoFrontier, 8(3): 110- 113.

Malathi, S. and Thippeswamy, S. 2013. The Proximal and mineral compositions of fresh water mussels Parreysia corrugata (Mullar,1774) from Tunga river in the western ghats, India. G.J.B.A. H.S. 2(3):165-170.

Patil, A. G. 2011. Protein changes in different tissues of freshwater bivalve Parreysia cylindrica after exposed to indoxacarb. Recent Research in Science and Technology, 3(3): 140-142.

Rahane, B. and Bhalla, R. 2018. Toxicant stress on protein and ascorbic acid contents in different tissues of freshwater bivalve Parreysia cylindrica from different reservoirs of Nashik District. India. Eco. Env. \& Cons, 24 (2): 856-860.

Rahane, B. and Bhalla, R.2019. Biochemical alterations due to heavy metals in different tissues of freshwater bivalve species at Chankapur reservoirs of Nasik district. (M.S). Journal of Environment and Biological sciences, 33 (1): 137-142.

Roe, J. H. 1967. In: Methods of Biochemical analysis Vol. 5, Ed. Blick, Interscience, New York: 44.

Tambe, R. S., Pulate, P. D. 2015. Protective role of 1-ascorbic acid on dichlorovos induced alterations in the protein contents of the fresh water bivalve, Parreysia cylindrica, Indian Journal of Applied Research, 5(9): 288-291.

Waykar and Tambe, 2014: Curative role of 1-ascorbic acid on dicofol induced alterations of the protein levels in the freshwater bivalve, Parreysia cylindrica. Indian Journal of Applied Research Volume, 4 (50): 641-644. 